\title{
JIUC \\ 1,2 \\ Extending the reach and impact of management research: a question of legitimacy
}

\section{8}

Received 6 March 2019 Revised 19 April 2019 Accepted 31 May 2019

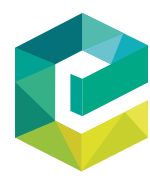

Journal of Industry-University Collaboration

Vol. 1 No. 2, 2019 pp. $58-78$

Emerald Publishing Limited 2631-357X

DOI 10.1108/JIUC-03-2019-0004

\author{
David J. Finch \\ Bissett School of Business, Mount Royal University, \\ Calgary, Canada \\ John Nadeau \\ Faculty of Applied and Professional Studies, \\ Nipissing University, North Bay, Canada \\ Bill Foster \\ University of Alberta, Augustana Campus, Edmonton, Canada \\ Norm O'Reilly \\ International Institute for Sport Business and Leadership, \\ College of Business and Economics, University of Guelph, \\ Guelph, Canada \\ Kim Bates \\ Department of Entrepreneurship and Strategy, \\ Ted Rogers School of Management, Ryerson University, \\ Toronto, Canada, and \\ Deryk Stec \\ Rowe School of Business, Faculty of Management, \\ Dalhousie University, Halifax, Canada
}

\begin{abstract}
Purpose - The issues associated with the production and dissemination of management research have been widely debated amongst administrators, scholars and policymakers for decades. However, few studies to date have examined this issue at the level of the individual scholar. The purpose of this paper is to view a management scholar's choice of knowledge dissemination (KD) outlets as a legitimacy judgment embedded in their social structure and community norms.

Design/methodology/approach - To explore this, the authors conduct a sequential mixed-methods study. The study uses qualitative methods, including one-on-one interviews $(n=29)$ and five workshops $(n=79)$ with administrators, management scholars, students and external community members (practitioners and policymakers). In addition, the authors analyzed the KD outcomes of 524 management scholars at seven Canadian universities drawn from a stratified sample of business schools.

Findings - The results of the research demonstrate the complex interaction between individual scholar-level factors, including socialization (degree type and practitioner experience) and tenure, and the institutional-level factors, such as strategic orientation and accreditation, and how these influence KD judgments. Specifically, the authors find that institutional factors (such as tenure and promotion) are a central predictor of scholarly $\mathrm{KD}$; in contrast, the authors find that individual-level factors including degree, professional experience and career stage influence non-scholarly $\mathrm{KD}$.
\end{abstract}

(c) David J. Finch, John Nadeau, Bill Foster, Norm O'Reilly, Kim Bates and Deryk Stec. Published in Journal of Industry-University Collaboration. Published by Emerald Publishing Limited. This article is published under the Creative Commons Attribution (CC BY 4.0) licence. Anyone may reproduce, distribute, translate and create derivative works of this article (for both commercial and non-commercial purposes), subject to full attribution to the original publication and authors. The full terms of this licence may be seen at http://creativecommons.org/licences/by/4.0/legalcode 
Originality/value - The results suggest that as management scholars face increasing pressure to demonstrate impact beyond academia, it may be more difficult than simply adapting the reward system. Specifically, the authors suggest that administrators and policymakers will have to consider individual factors, including their academic training (including interdisciplinary training), previous practitioner experience and career stage.

Keywords Legitimacy, Business schools, Management research

Paper type Research paper

\section{Impact of management research}

Few scholars would debate that a critical function of management research is the creation and dissemination of new knowledge (Engwall and Kipping, 2004; Romme, 2017). However, one of the ongoing debates is the question of - knowledge for whom? (Aguinis et al., 2014; Erkut, 2002). At its core, this debate is rooted in a question of legitimacy; because as Certo et al. (2010, p. 293) state "a scholar establishes academic legitimacy through scholarly productivity." Some management scholars view the primary audience of their research to be peers (e.g. Kieser and Leiner, 2011). These scholars argue that attempting to extend theory-driven research outside the academia risks its theoretical contribution. In contrast, other management scholars contend that research should extend beyond the academia to broader societal audiences (Aguinis et al., 2014; Finch et al., 2016; Perriton and Hodgson, 2013). This divide is expressed by Gibbons et al. (1994) who propose that the production of knowledge should be viewed as two distinct modes: Mode 1 knowledge is theoretically centric discipline-based research addressed to the academy and Mode 2 knowledge is transdisciplinary research focused on application and addressed to audiences outside the academy.

The debate associated with the different forms of research and to whom this research seeks to reach has significant implications on the type of research a scholar conducts and where they choose to disseminate their work (Marcos and Denyer, 2012; Adler and Harzing, 2009; Boyer, 1998). In particular, management scholars make decisions about where to disseminate their work based on the perceived legitimacy of a chosen knowledge dissemination $(\mathrm{KD})$ outlet. This is reinforced in post-secondary institutions by the decisions associated with hiring, tenure and promotion. Because a committee of a scholar's peers (Fairweather, 2002; Adler and Harzing, 2009) decides on the criteria used to formalize these processes through hiring, tenure and promotion criteria and associated journal ranking systems (e.g. Chartered Association of Business Schools Journal Guide) (Adler and Hansen, 2012) how this audience perceives the legitimacy of particular dissemination outlets is, arguably, essential for the successful navigation of one's academic career.

However, the academy is not the only audience that many management scholars seek to reach. More recently, studies on the impact of management research has focused on non-scholarly audiences (Finch et al., 2016; Kantola and Seeck, 2011; Marcos and Denyer, 2012; Paton et al., 2014). For some, it is no longer acceptable for management research to be directed solely to those in the academy. For example, Perriton and Hodgson (2013) argue the advancement of actionable knowledge though academic and practitioners "co-production." They argue that other audiences are of the utmost importance and should be weighted equally or more than the concerns of the academy. Thus, it is not surprising that in the pursuit of legitimization, management scholars focus on $\mathrm{KD}$ outlets that are rooted in the accepted norms of their intended audiences. And although the dissemination of management research remains focused squarely on peer-reviewed journals that serve almost exclusively scholars (Aguinis et al., 2014; Pettigrew et al., 2014) there are indications that other $\mathrm{KD}$ outlets, directed at different, non-scholarly audiences, are increasing in legitimacy.

As noted, the issues associated with the production and dissemination of management research have been widely debated amongst administrators, scholars and policymakers 
JIUC
1,2

for decades. However, few studies to date have examined this issue at the level of the individual scholar (Hommel and Thomas, 2014). Consequently, this study examines the following research question:

$R Q 1$. What individual and institutional level factors influence the choice of dissemination outlet for management research?

To explore this question, we conduct a sequential mixed-methods study. The study uses qualitative methods, including one-on-one interviews $(n=29)$ and five workshops $(n=79)$ with administrators, management scholars, students and external community members (practitioners and policymakers), to develop a conceptual model associated with the antecedents of $\mathrm{KD}$ of management research. Based on our qualitative findings and relevant literature, an analysis was conducted of the $\mathrm{KD}$ outcomes of 524 management scholars at seven Canadian universities drawn from a stratified sample of business schools. This analysis incorporates nine different $\mathrm{KD}$ outlets ranging from peer-reviewed journals to textbooks to social and print media.

\section{Conceptual development}

We view a management scholar's choice of KD outlets as a legitimacy judgment embedded in their social structure and community norms. This community may be internal to the institution of their current appointment, an external peer in their discipline (e.g. editor of a prestigious journal) or external to their institution and their discipline. For example, a scholar's choice to publish in one journal over another, to actively engage practitioners, or to do a media interview are framed by social judgments of what is legitimate (and what is not). As Suchman (1995, p. 574) states: "Legitimacy is socially constructed in that it reflects congruence between the behaviors of the legitimated entity and the shared (or assumedly shared) beliefs of some social group." Maintaining legitimacy facilitates the flow of resources from stakeholders to an actor (Pfeffer and Salancik, 1978; Rynes and Brown, 2011). Many attributes can be subject to legitimation pressures, such as organizational structures, strategies, practices and rhetoric (Deephouse, 1996; Suddaby and Greenwood, 2005; Lounsbury and Crumley, 2007). The particular attributes that are important for maintaining legitimacy are contingent on the actor's context, especially on the particular sources that confer legitimacy (Deephouse and Suchman, 2008). Consequently, we propose that the choice of $\mathrm{KD}$ outlets are subject to legitimation pressures, which are embedded in organizational structures, practices and rhetoric within the academy, an institution (Deephouse, 1996; Lounsbury and Crumley, 2007) and external communities (i.e. practice).

Recently, management scholars have called for research into the antecedents of legitimacy judgments at the individual level because individuals collectively influence the norms, laws and cognitive categories of a social system (Tost, 2011). As such, this lens represents a bottom-up approach to institutional research (Scott, 2008). In the context of KD, how are legitimacy judgments formed and how do they influence KD outcomes? Building on the conceptual framework proposed by Finch et al. (2016), we argue that management scholars define peers as a critical audience because they possess the ability to pass judgment on the legitimacy of KD outlets. This judgment is then diffused through the system as a recursive feedback loop. Yet, as discussed previously, the shift toward measuring impact on audiences outside academia has meant that different audiences are growing in importance and can influence the choice of $\mathrm{KD}$ outlets by management scholars. Consequently, understanding the reasons why management scholars choose different $\mathrm{KD}$ audiences represents vitally important questions to answer. Figure 1 presents our proposed $\mathrm{KD}$ as a Legitimacy Judgment framework.

\section{Qualitative study}

Our first study responds to Jensen's (2010) call for additional in-depth qualitative research that explores the factors that contribute $\mathrm{KD}$ outcomes at an individual scholar level. 


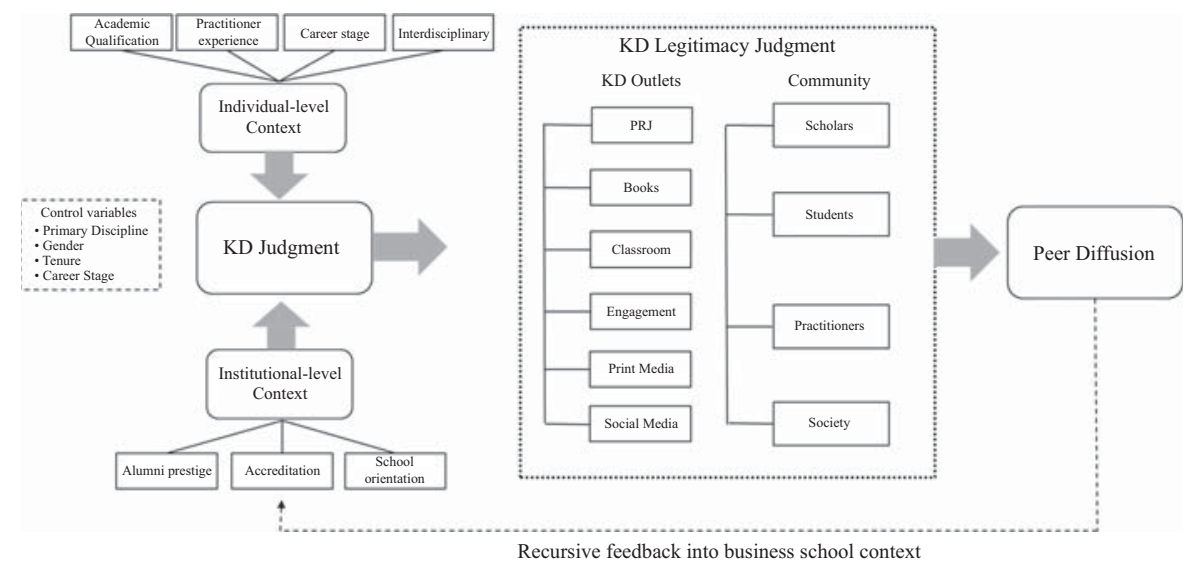

\section{Impact of management research}

Our study incorporated two qualitative methods. The first was a series of one-on-one interviews $(n=29)$ to provide insight into a person's subjective interpretations, beliefs, perceptions and frames of reference of the specific topic under study. The second method involved group workshops $(n=50)$, with the goal of exploring the interaction among a diverse population of business school stakeholders. In total, our study included 79 internal and external stakeholders from five different business school audiences, from four countries (Canada, USA, UK and Australia).

\section{Method}

\section{Data collection}

Management research workshops. Following the model of Davies et al.'s (2005) five workshops was held between October 2015 and August 2016 either independently or in conjunction with academic conferences or meetings. This included the Academy of Management Annual Conference, the Administrative Sciences Association of Canada Annual Conference, the Canadian Federation of Business School Deans Associate Deans of Research Conference, Business School Research Network Annual Meeting and the Alliance for Sport Business Annual Conference. Participation in these workshops was voluntary. The workshops varied in size from 8 to 24 and ranged from $90 \mathrm{~min}$ to $2 \mathrm{~h}$. The workshops were composed of academic members $(n=53)$ and non-academic members $(n=26)$. During the workshops, participants were placed into working groups. Each of these workshops maintained a consistent format. From a process perspective, smaller working groups (four to eight people) were formed and assigned a facilitator. The first phase involved individual members of these working groups to submit written responses to a series of questions. This was followed by a facilitated exercise that had each working group identify composite themes. All participant and working group level documentation was submitted to the researchers for transcription and consolidation.

One-on-one interviews. The second phase of the study involved standardized, semi-structured one-on-one interviews based on an open-ended protocol. A total of 29 interviews were completed based on purposeful sampling with senior administrators $(n=11)$, faculty $(n=10)$ and external members $(n=8)$ from four countries (Canada, USA, UK and Australia). The open-ended format provides both the structure to examine the major themes, while ensuring objectivity and reflection on key issues (Soule and Edmondson, 2001). The interview protocol was consistent for all interviewees with the questions exploring the antecedents of $\mathrm{KD}$ outcomes. Each participant was interviewed in 
JIUC
1,2

person or via telephone and lasted between 33 and 128 min. All interviews were digitally recorded and transcribed.

\section{Data analysis}

The objective of the qualitative portion of this research was to gain insight from the personal experiences of those who participated (Creswell, 1998). This methodology provides insight into an individual's perceptions, enables new meanings to emerge, and recognizes that the experiences of the participants are highly personal and context specific, with the goal of extracting composite themes across the diverse participants (Linehan and Walsh, 2001). To ensure that the desired contributions are made, a range of techniques to synthesize and verify the results to maximize reliability were incorporated (Soule and Edmondson, 2001).

A single researcher reviewed both the audio recordings and transcripts for each interview in its entirety to provide a holistic perspective of the interviews and enable the coding of major themes. This same researcher reviewed the raw notes from each working group for the five workshops since it is critical that the synthesis process be done in a manner that elevates the findings to composite themes without losing the integrity of each participant's or working group's contribution (Linehan and Walsh, 2001). A separate document was maintained by the researcher outlining all of the participants and working group contents removed during this analysis. This enabled the researchers to ensure that no major themes were lost doing the synthesis and to begin identifying composite meaning units at the individual participant level for the interviews and the working group level for the workshops. The first-level coding identified 16 composite themes associated across the interviews and workshops.

Two additional researchers reviewed the composite themes, the supporting excerpts from the transcripts and the working group notes, and focused on eliminating any overlapping themes in a manner that did not compromise the integrity of the contribution from both the interviewees and working groups (Linehan and Walsh, 2001). In total, findings from the interviews and workshops are summarized under five major themes:

(1) management research serves diverse audiences;

(2) the individual scholar is the key unit of analysis;

(3) the role of peers is essential to career development;

(4) scholar socialization is an antecedent of $\mathrm{KD}$ judgments; and

(5) institutional-level pressure is an antecedent of $\mathrm{KD}$ judgments.

\section{Results}

\section{Theme 1: management research serves diverse audiences}

Participants were asked to define the core audiences of management research and provide supporting rationale to their importance. A composite theme that emerged was that "impact" is an audience-level construct. This is consistent with management scholars who argue that "knowledge" is "guided by contextually determined interpretive schemes, norms, and power relationships that share sense making" (Mohrman et al., 2001, p. 359). Through the interviews and workshops, four dominant macro-level audiences emerged: scholars (including scholarly outlets and funding agencies), students (including alumni), practitioners, and society (including government ministries and legislatures that fund public universities). Based on output from our qualitative research, the macro-definition for each audience is.

Scholars. A group of individuals who make intellectual contributions to the advancement of management. The contribution may include both theory and practice. 
Students. A group of individuals who take a credit or non-credit program at a business school. The scope includes both past, present and future students.

Practitioners. Individuals or groups who engage in business or management. At an individual-level it includes all individuals who engage in business or management. At a group-level, it includes all organizations (e.g. profit, non-profit, government), professional associations (e.g. CPA) and industries.

Society. Society was a highly abstract term used by participants. In general, it was defined in terms of a group of individuals with a common interest, which may be framed by dimensions of geography (e.g. city or country), language, history, culture or interest.

\section{Theme 2: the individual scholar is the key unit of analysis}

Participants noted that the decision by scholars to disseminate research to different audiences is framed by whether the scholar perceives these audiences to be both salient and valuable. For example, as one dean notes: "At a research school disseminating research beyond high ranked journals is rarely valued. The irony is many scholars don't appreciate that publishing in a newspaper like the New York Times is more difficult than most ranked journals and the reach is exponential." Thus, participants argue that when exploring the antecedents of KD outcomes, the individual scholar is the key unit of analysis.

\section{Theme 3: the role of peers is essential to career development}

There was consensus among internal participants (both administrators and scholars) that in the context of academia, peers (including scholars and administration) possess an unusual amount of influence on a scholar's career success. The most cited examples include hiring, tenure and promotion committees, appointment to editorial boards, election to academy executives and internal committee work. Participants often noted the lack of hierarchical power in academia amplifies the role and consequently the importance of peers.

With specific reference to research, it was often cited that most hiring, tenure and promotion criteria are subjective and therefore open to interpretation by peers and committees. Examples include the often intentionally undefined number (and associated rank) of journals publications required for tenure. As this is often not explicitly defined, the result is that individual member's perceptions of what defines legitimate outlets of $\mathrm{KD}$ become highly influential. Other examples offered ranged from how scholars engage students and society in research activities. It was noted that in many circumstances the views of a scholar's peers may align to the mission of the institution, however, in most circumstances the specific application of the "mission" was left to the individual to interpret. As one dean notes:

When we get in the committee room where it's the most crucial to people's careers, we can't be say broader societal impact is important everywhere else but not in there. I think that really just comes around with keeping hammering home the fact that we develop alternative legitimate metrics of impact. You get faculty to buy into the notion of why these things are important and as a lot of our peers quite frankly don't understand the concept of impact beyond journals. So I think a piece of it is education, but a bigger piece is cultural, and I think we probably have a lot of way to go before those kinds of impact are valued at the level that I 'd like to see them valued as.

\section{Theme 4: scholar socialization is an antecedent of KD judgments}

Participants identified the influence of both academic and practitioner socialization as providing an important foundation for $\mathrm{KD}$ judgments and outcomes. First, many participants identified the socialization process associated with doctoral training as framing a scholar's perception of KD legitimacy. It was noted by several participants that academic socialization is also influenced by the culture and values of the institution and the discipline 
in which they completed their academic training; and more specifically, the values of their doctoral supervisor. This finding is consistent with existing literature (Chia and Holt, 2008; Van de Ven and Johnson, 2006). Second, participants also identified that full-time practitioner experience contributes to framing the value system of a management scholar. Specifically, participants noted that scholars with previous practitioner experience have an increased desire to conduct research that contributes to apply problem solving. For example, as one scholar notes:

I did my $\mathrm{PhD}$ after 15 years working in finance. I remember I gave a speech to the local chapter of the national finance association, 60 people, all bankers, analysts and money managers. Two hours of Q \& A. It was awesome, great response with lots of emails afterwards. Honestly, not to sound arrogant, but it takes fifteen years of experience in industry to be both interested in and capable of channelling academic research in a forum like that. Without that, your world focuses almost solely around the FT45. I think this diversity brings better outcomes. It's perspective, and to be successful, it's about integrating more and segregating less.

Based on output from our qualitative research, we classify scholars into one of three socialization categories. First, academically qualified (AQ) are scholars who possess a terminal degree in their field but possess not full-time practitioner experience in their field prior to their academic appointment. Second, professionally qualified (PQ) scholars are those who possess full time practitioner experience in their field but do not possess a terminal degree. The final category of scholars is those who possess both a terminal degree and full-time practitioner experience in their field. We defined these as bridge scholars.

Finally, career stage was identified by participants as having significant influence on a scholars KD outcomes. Specifically, it was identified by participants that the tenure and promotion process frame the influence and role of a scholar's peers. In this context, early career scholars were noted to pursue peer-reviewed publications (often linked to their doctoral research). Whereas, middle to later career scholars, though valuing peer-reviewed journals, possess greater flexibility to pursue other outlets, ranging from books to industry publications to active practitioner engagement.

\section{Theme 5: institutional-level pressure is an antecedent of KD judgments}

Participants identified that both formal and informal business school pressures influence KD judgments and outcomes. Participants emphasize that one of the most significant barriers to business school evolution is the acknowledgment that they are part of a broader university and are constrained by both culture and policy. Business school factors that influence a scholar's KD outcomes that were explicitly identified by participants include: mission/ strategic orientation, institutional ranking systems and accreditation requirements.

Strategic orientation. Participants often cited the foundational role of institutional culture, framed by the strategic orientation and vision of their home university and more specifically, their business school. It was noted that the strategic orientation and mandate of the institutions were codified in the hiring, tenure and promotion criteria. As a result, a scholar at a research-intensive university will experience different forms of institutional pressures when compared to a scholar at a teaching-oriented university. As one dean notes:

So the incentives that you provide through tenure and promotion drive people towards different behaviours. At our school we recognize that the FT-45 is a great group of journals, but they don't always reflect the type of research that our researchers are interested [in]. They certainly don't reflect the niches that are available in the management school and we want to encourage and recognize research that aligns to our goals as a school.

Accreditation. Participants identified the influence of accreditation bodies, such as AACSB and EQUIS, as having an influence on KD outcomes. Specifically, they argue that these 
systems embed specific values associated with different $\mathrm{KD}$ outlets, the most often cited being peer reviewed journals. However, numerous administrators noted this pressure may be evolving as accreditation agencies evolve their definition of scholarship. The new AACSB Standard 15 was identified often by participants as evidence of this, yet it was noted that it will take years before the new standards are implemented and embedded in the culture of a business school. One dean stated that the introduction of Standard 15 has legitimized engagement with practice. "One of the positive levers that's been very helpful for management research has been the changes to AACSB accreditation because things like professional currency are now spoken about, we now proactively ask scholars. What are you doing to keep up on the profession?"

Business school rankings. Participants, specifically administrators, argue that business school ranking systems can have an effect on the values of a business school, which are then codified in tenure and promotion criteria. Therefore, in the pursuit of global rankings, a business school may seek to incentivize specific forms of KD by scholars. This most often includes pressures to publish in globally ranked journals, but increasingly includes pressures to engage non-scholarly audiences through broader forms of $\mathrm{KD}$ including print media, books and executive education (Paton et al., 2014). As one senior scholars member states: "So every dean knows that ranking is a terrible system, and yet they have no choice. They feel handcuffed to play to those metrics, and we'll continue to do so as long as they exist, which filters into every single activity in their playbook."

\section{Qualitative research summary and model development}

The initial results identified four macro-level audiences and the diverse KD outlets available to scholars (see Table I).

\begin{tabular}{|c|c|c|c|}
\hline KD outlets & Workshop support & Interview support & Literature support \\
\hline \multicolumn{4}{|l|}{ Scholar KD } \\
\hline Referred publication & レ & レ & Connelly and Gallagher (2010) \\
\hline Referred conference & 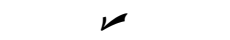 & $\swarrow$ & Connelly and Gallagher (2010) \\
\hline Edited research book & 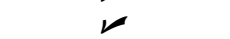 & 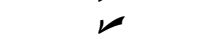 & Adler and Harzing (2009) \\
\hline Research Gate & 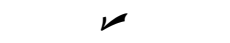 & 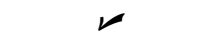 & Thelwall and Kousha (2014) \\
\hline \multicolumn{4}{|l|}{ Student KD } \\
\hline Course-level engagement & レ & 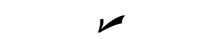 & Aguinis et al. (2014) \\
\hline Textbook publication & レ & 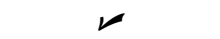 & Burke and Rau (2010) \\
\hline \multicolumn{4}{|l|}{ Practitioner KD } \\
\hline Book publication & レ & $\swarrow$ & Jensen (2010) \\
\hline Professional publication & & 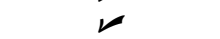 & Thorpe et al. (2011) \\
\hline Professional conferences & & 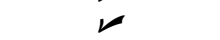 & Bekkers and Freitas (2008) \\
\hline Research collaboration & レ & & Marcos and Denyer (2012) \\
\hline Active research engagement & & & Bekkers and Freitas (2008) \\
\hline LinkedIn & $\swarrow$ & 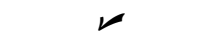 & Lim et al. (2014) \\
\hline \multicolumn{4}{|l|}{ Societal KD } \\
\hline Social media & レ & レ & Aguinis et al. (2014) \\
\hline Twitter & レ & & Aguinis et al. (2014) \\
\hline YouTube & & & Aguinis et al. (2014) \\
\hline Print media & & 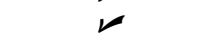 & Jensen (2010) \\
\hline
\end{tabular}

Notes: UD, unidirectional; BD, bidirectional

Table I. KD outlets by audience 
JIUC

1,2

66

Based on these results (Tables I and II), we propose the following model to test the antecedents of different KD outcomes. This test will involve an empirical test of a sample of 524 faculties from seven Canadian business schools.

\section{Quantitative model testing}

\section{Method}

The quantitative data were sourced from tenured or tenurable faculty at seven Canadian business schools. This process involved a multiple step stratification that identified a final sample of 524 faculty members from business schools stratified by mission and geography. The overall research design adapted the biographical content analysis used by Dietz and Bozeman (2005).

\section{Initial coding scheme}

The development of a consistent coding scheme is essential for conducting content analysis (Dietz and Bozeman, 2005; Wu et al., 2010). In this study, KD outlets categories were adapted from Jensen (2010)[1].

\section{Sampling procedure}

As a first step in our sampling process, we assessed both the quality and the availability of faculty information from all 58 university business schools in Canada[2]. This involved a random sample of three biographies from each of these universities. In doing so, two authors coded the faculty data based on the codebook criteria. The quality of a school's faculty biographical information was defined as "excellent" if the university provided access to a full curriculum vitae or offered a dedicated page biographical page for each faculty member. As a result, 38 percent of the university business schools (23) had excellent faculty-level data; compared to 43 percent which had good and 19 percent which had poor faculty-level data. Based on this, we stratified the 23 "excellent" schools by strategic orientation and geography (Palmer and Short, 2008). Strategic orientation was based on adapting the university categories defined by Statistics Canada (2009): researchintensive universities (defined as a member of the U15 group of research schools[3]), comprehensive universities, and primarily undergraduate universities. The resulting

\begin{tabular}{|c|c|c|c|}
\hline Antecedents & Workshop support & Interview support & Literature support \\
\hline \multicolumn{4}{|l|}{ Individual-level factors } \\
\hline Academic qualification & $\nu$ & 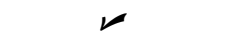 & AACSB (2013) \\
\hline Full-time practitioner experience & $\nu$ & 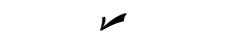 & Dietz and Bozeman (2005) \\
\hline Active participant engagement & $\nu$ & 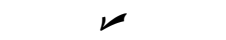 & Dietz and Bozeman (2005) \\
\hline Discipline expertise & & 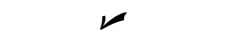 & Dietz and Bozeman (2005) \\
\hline Interdisciplinary appointment & $\nu$ & 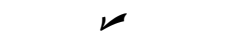 & Clarke et al. (2013) \\
\hline Alumni affiliation & $\nu$ & $\nu$ & Bedeian et al. (2010) \\
\hline Faculty rank & 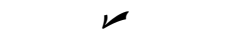 & 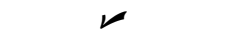 & Gomez-Mejia and Balkin (1992) \\
\hline Tenure status & $\nu$ & $\nu$ & Adler and Harzing (2009) \\
\hline Gender & & $\nu$ & AACSB (2013) \\
\hline Career stage & & & Brown (2005) \\
\hline \multicolumn{4}{|l|}{ Institutional-level factors } \\
\hline Mission/Orientation & $\swarrow$ & 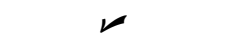 & Palmer and Short (2008) \\
\hline Accreditation demands & $\nu$ & $\nu$ & Everard et al. (2013) \\
\hline Ranking systems & $\nu$ & 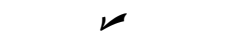 & Palmer and Short (2008) \\
\hline University size & & 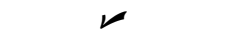 & Landry et al. (2007) \\
\hline Association demands & 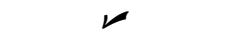 & 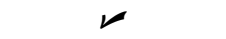 & Durand and McGuire (2005) \\
\hline
\end{tabular}

Table II. Individual and institutional level factors

\author{
AACSB (2013) \\ Dietz and Bozeman (2005) \\ Clarke et al. (2013) \\ Bedeian et al. (2010) \\ Gomez-Mejia and Balkin (1992) \\ Adler and Harzing (2009) \\ AACSB (2013) \\ Palmer and Short (2008) \\ Everard et al. (2013) \\ Palmer and Short (2008) \\ Durand and McGuire (2005)
}


sample included a minimum of one business school from each university category $(n=7)$ and each of Canada's four geographic regions[4].

All further data collection was done by two authors who developed a codebook and conducted a pilot of ten faculty profiles from each of the seven schools in this study. This involved each researcher coding these profiles individually and reviewing areas of inconsistency (Wong et al., 1995; Dietz and Bozeman (2005). The remaining faculty at these seven schools were coded by a single author. Coding inconsistency was reviewed by the lead author on a weekly basis. Our final sample included 524 tenured or tenurable faculty.

The set of variables incorporated in the study are summarized in Table III including dependent variables (peer reviewed publications, FT45 publications, bridge journal publications, book publications, engagement with students, engagement with practice, print media and social media engagement), independent variables (academic qualification, fulltime practitioner experience, interdisciplinary appointment, $\mathrm{PhD}$ program rank, strategic orientation, accreditation status and school rank) and control variables (gender, tenure, career stage, faculty rank and primary discipline).

\section{Results}

Faculty from research-intensive schools represent the largest proportion of faculty in our sample ( 45.3 percent), and the majority of faculty ( 64.5 percent) are from accredited business schools. A large proportion (82.8 percent) of the sample possessed a terminal degree. The majority of the sample (58.1 percent) is categorized as AQ faculty, 17.2 percent are $\mathrm{PQ}$ faculty and 24.7 percent are bridge qualified faculty. In addition, 9.4 percent of the sample currently hold an interdisciplinary appointment. The majority (76.9 percent) of faculty biographic data offers evidence of peer reviewed journal publishing, 27.2 percent are involved in active practitioner engagement and 18.4 percent demonstrate evidence of textbook publishing. A majority (51.6 percent) had engaged print media in the past and 69.2 percent used LinkedIn as the most popular social media form, followed by ResearchGate at 51.4 percent. Table IV provides a summary.

Table $\mathrm{V}$ presents the results of $\mathrm{KD}$ outlets by socialization category. There is a significant variance between the socialization categories in 7 of the $13 \mathrm{KD}$ outlets. Not surprising, outlets related to scholarly $\mathrm{KD}$ (PRJ and ResearchGate) confirm that both $\mathrm{AQ}$ and bridge faculty are significantly different from PQ faculty. For in-class and practitioner engagement, bridge faculty are distinct from the two other socialization categories. For example, 19.4 percent of bridge faculty offer evidence of integrating their research in the classroom, compared to only 5.6 percent of AQ and 3.3 percent of PQ faculty. Similarly, 37.2 percent of bridge faculty engage practice, compared to 14.1 percent of $\mathrm{AQ}$ faculty and 31.1 percent of $\mathrm{PQ}$ faculty. Finally, socialization appears to not significantly influence broader $\mathrm{KD}$ outlets associated with books, social and print media.

\section{Data analysis}

A binomial logistic regression was conducted to examine the combined effects of the independent variables on the KD outcomes as the dependent variables, assess the model and test the hypotheses (Pangarkar, 2007). In doing so, a total of 12 logistic regression models were run, one for each of the KD outlets in our study. A correlation analysis identified strong relationships among several variables in our model, thus to address concerns about collinearity (see Tabachnick and Fidell, 1996), an exploratory factor analysis was run. As a result, full-time practitioner experience and socialization loaded as a single construct in excess of 0.80 . Further, career stage and tenure loaded as a single construct with both variables in excess of 0.60 . Finally, the home school ranking and strategic orientation loaded as a single construct in excess of 0.80 . Thus, we removed socialization, career stage and home school ranking from the analysis.

\section{Impact of management research}


Dependent variables

Evidence of peer-reviewed Evidence of publication of up to three articles in an Australian Business Deans publication (1-3 articles) Council (ABDC) journal. No =0; Yes $=1$

Evidence of peer-reviewed Evidence of publication of four or more articles in an Australian Business Deans publication (4+ articles) Council (ABDC) journal. No $=0$; Yes $=1$ 45 (2012) journal list. No $=0$; Yes $=1$

Evidence of bridge journal A faculty member was coded as having published in a bridge journal when there publication was evidence they authored an article in a peer-review journal that defines practitioner and academics s as a primary audience (e.g. California Management Review). No $=0$; Yes $=1$

Evidence of book publication (other) Evidence of book publication (primary author, chapter author or editor). $\mathrm{No}=0$; Evidence of book publication (text) Yes $=1$

A faculty member was coded as being engaged in explicit $\mathrm{KD}$ through textbooks (primary author, chapter author or editor) if there was a book listed in the biographic profile. No $=0$; Yes $=1$

Evidence of active A faculty member was coded as being actively engaged with students when there engagement with students is evidence of actively using their research in their teaching. The most common example of this was explicit use of a published paper in a course syllabus. No $=0$; Yes $=1$

Evidence of active $\quad$ Evidence of engagement in practice including: (a) collaborative industry research; engagement with practice and (b) consulting (e.g. expert witness appointments, board appointments, management consulting). (Marcos and Denyer, 2012). $\mathrm{No}=0$; Yes $=1$

Evidence of print media engagement A faculty member was coded as being engaged in print media if there was explicit evidence that they either authored an article or were interviewed for an article in a search of Canadian or American print media. The Canadian Newsstand Complete and Newspaper Source databases were used for this search. No=0; Yes $=1$

Evidence of social media A faculty member was coded as being engaged if they have an account in (a) engagement Twitter; (b) LinkedIn; (c) YouTube; (d) Research Gate. Each were coded individually. $\mathrm{No}_{\mathrm{o}}=0$; Yes $=1$

Independent variables Academic qualification

Full-time practitioner experience Interdisciplinary appointment $\mathrm{PhD}$ program rank

Strategic orientation
Highest academic credential received. $0=$ No degree; $1=$ Bachelors; $2=$ Masters; $3=$ Other terminal; $4=\mathrm{PhD}$

Evidence of full-time practitioner experience prior to their academic appointment (excluding internships and practicums). $\mathrm{No}=0 ; \mathrm{Yes}=1$

When a faculty member holds a cross appointed to another department at the university (inside or outside of the business school). No $=0$; Yes $=1$

Based on the Financial Times, three-year Global PhD rankings (2013-2015). Considers the total number of $\mathrm{PhD}$ graduates and their placement at ranked business schools. Unranked PhD programs were coded as "unranked" as a 0 The strategic orientation of a business school was measured as one of three categories following Statistics Canada (2009)

Research intensive: the first category (coded as 3 ) is composed of business schools with a research intensive orientation. This was defined for all business schools who are members of the U15 group of universities (a formal association of the leading 15 research universities in Canada). Coded as 3

Comprehensive: the second category (coded as 2) includes business schools with a primarily teaching orientation and located at an undergraduate university (Statistics Canada, 2009). Coded as 2

Primarily Undergraduate: the third category (coded as 1) consists of business schools with what Statistics Canada (2009) define as a "comprehensive" orientation, who seek to balance their focus on teaching and high quality research. As a result, the degree focus for these schools is primarily at the Bachelor and Master levels. Coded as 1

Table III. 


\begin{tabular}{|c|c|c|}
\hline Variable & Measure & it \\
\hline Accreditation status & $\begin{array}{l}\text { A business school was coded as being AACSB or EQUIS accredited if they were } \\
\text { accredited as of April } 1,2015 \text {. No }=0 ; 1=\text { Yes }\end{array}$ & Irch \\
\hline $\begin{array}{l}\text { Home business school } \\
\text { rank }\end{array}$ & $\begin{array}{l}\text { Rank of the business school based on the Financial Times Global } 100 \mathrm{MBA} \\
\text { rankings. If a business school was not ranked it was coded as a } 0\end{array}$ & \\
\hline Control variables & Male $=1$ Female $=0$ & 69 \\
\hline Tenure & Tenured $=1$. Non-tenured $=0$ & \\
\hline Career stage & $\begin{array}{l}\text { Defined as the year a faculty member was awarded their highest academic } \\
\text { credential }\end{array}$ & \\
\hline Faculty rank & $\begin{array}{l}\text { 1. Lecturer; 2. Assistant professor; 3. Associate professor; 4. Full professor; } \\
\text { 5. Administrator }\end{array}$ & \\
\hline Primary discipline & $\begin{array}{l}\text { Defined based on their current academic appointment. 1. Accounting; } 2 . \\
\text { Management; } 3 \text {. Business law; } 4 \text {. Economics; } 5 \text {. Entrepreneurship; } 6 \text {. Finance; } \\
\text { 7. Hospitality; } 8 \text {. Human Resources; } 9 \text {. Information Systems and Technology; } \\
\text { 10. International Business; } 11 \text {. Marketing and Sales; } 12 \text {. Other (Construction } \\
\text { Management); 13. Operations Management/Supply Chain/Service Management }\end{array}$ & Tal \\
\hline
\end{tabular}

Table VI (Panels a and b) reports the results of the binomial logistic regression models. Overall, based on the Nagelkerke $R^{2}$ results, 9 of the 12 models report to be a good fit for the data. Moreover, the omnibus tests using $\chi^{2}$ statistics all were significant for 9 of the 12 models, offering support that there is a significant relationship between the independent and dependent variables in these models.

The Nagelkerke $R^{2}$ for FT45 (0.471) and 4+ (0.372) suggests the model is a good fit. At an institutional level both strategic orientation and accreditation influences the model. Notably, 67.8 percent of faculty at a researcher-centric university have published in an FT45 journal, compared to 5.9 percent at undergraduate schools $(p<0.001)$. Similarly, 46.8 percent of faculty at accredited schools have published in an FT45 journal compared to only 17.0 percent of faculty at non-accredited schools $(p<0.010)$. At the individual-level, both PRJ models are influenced significantly by terminal degree and tenure. For example, 47.6 percent of tenured faculty have published in an FT45 journal, compared to 35.1 percent of non-tenured faculty. Finally, holding an interdisciplinary appointment predicts FT45 publications.

For Bridge PRJ, the Nagelkerke $R^{2}$ is 0.124 . For this model, strategic orientation is significant as 8.4 percent of faculty at a research-intensive school have published in a bridge journal compared to none for undergraduate schools and 5.9 percent for comprehensive schools $(p<0.05)$. At an individual level, 7.6 percent of tenured faculty have published in a bridge journal compared to 3.1 percent of untenured faculty $(p<0.05)$. However, neither terminal degree nor full-time practitioner experience have influence on publishing in a bridge journal.

ResearchGate is consistent with the PRJ models in that we find strategic orientation and accreditation predict its usage. The individual factors that influence this model are terminal degree and tenure, with Nagelkerke $R^{2}$ for this model at 0.262 .

For classroom engagement, 10.9 percent of faculty at undergraduate schools offer evidence of engaging their research in the classroom, compared to 4.2 percent of research-intensive school faculty $(p<0.01)$. At the individual level, terminal degree, practitioner experience, interdisciplinary appointments and tenure predict classroom use. For example, 18.4 percent of those with an interdisciplinary appointment use research in their class, compared to 7.6 percent of those without $(p<0.001)$. In addition, 44.3 percent of those with tenure use research in class, compared to only 20.6 percent of those without $(p<0.001)$. The Nagelkerke $R^{2}$ for this model is 0.141 . 


Variable Total

$\%$

Total business schools

Total faculty positions

Gender

Male

Strategic orientation

Research-intensive universities 237

Comprehensive universities

Primarily undergraduate universities

Accreditation

Accredited (AACSB or EQUIS)

School ranking

Ranked

Academic qualification

Terminal degree

Other

Year awarded highest academic credential

Pre 1970

1970-1979

1980-1989

1990-1999

7.1

2000-2009

16.9

2010-2014

Tenured

PhD program rank

Ranked $\mathrm{PhD}$ program

Socialization category

Professionally qualified

Academically qualified

Bridge qualified

Interdisciplinary appointment

PRJ publication level

No publications

1-3 publications

$>4$ publications

76.1

FT45 publication

Bridge publication

42.8

Direct classroom engagement

Book publishing

Book publishing (other)

Book publishing (textbook)

12.0

Active practitioner engagement

18.4

Social media

YouTube

14.0

LinkedIn

Research Gate

69.2

Twitter

51.4

Table IV.

Print media 


\begin{tabular}{|c|c|c|c|c|c|}
\hline KD outlets & AQ faculty & Bridge faculty & PQ faculty & $\chi^{2}$ & $\ln$ \\
\hline PRJ (FT45) & 50.3 & 50.4 & 6.7 & 0.000 & rch \\
\hline PRJ (1-3) & 82.6 & 84.5 & 42.2 & 0.000 & \\
\hline PRJ (4+) & 63.8 & 65.1 & 23.3 & 0.000 & \\
\hline PRJ (Bridge) & 5.3 & 10.1 & 2.2 & 0.040 & \\
\hline ResearchGate & 61.2 & 50.4 & 20.0 & 0.000 & \\
\hline In-Class & 5.6 & 19.4 & 3.3 & 0.000 & 7 \\
\hline Textbook publishing & 17.4 & 20.9 & 17.8 & 0.683 & \\
\hline Other book publishing & 34.7 & 41.9 & 29.2 & 0.142 & \\
\hline Practitioner engagement & 14.1 & 37.2 & 31.1 & 0.000 & \\
\hline LinkedIn & 67.8 & 72.9 & 68.9 & 0.575 & Table V. \\
\hline YouTube & 15.1 & 14.7 & 8.9 & 0.311 & Sample by \\
\hline Twitter & 9.9 & 10.1 & 13.3 & 0.632 & socialization \\
\hline Print media & 48.7 & 56.6 & 54.4 & 0.272 & classification \\
\hline
\end{tabular}

Next, we find that 25.3 percent of faculty at research-intensive schools have published textbooks, compared to 14.9 percent of faculty at undergraduate schools $(p<0.001)$. Similarly, 21.2 percent of faculty at accredited schools have published textbooks, compared to 12.2 percent at non-accredited schools. Finally, 23.8 percent of tenured faculty have published a textbook, compared to 9.2 percent of non-tenured faculty. Similarly, for other book publishing, we find that strategic orientation and tenure predict KD. The Nagelkerke $R^{2}$ for textbook is 0.129 and other book is 0.113 .

Results indicate that no institutional-level variables influence engagement in practice. To the contrary, we find that 34.7 percent of those with full-time practitioner experience engage practitioners, compared to 14.1 percent of those without $(p<0.001)$. In addition, we find that 42.9 percent of faculty with interdisciplinary appointments are engaged in practice, compared to 20.7 percent of those without $(p<0.01)$. The Nagelkerke $R^{2}$ for this model is 0.117 .

When we consider engagement with the three social media outlets of LinkedIn, YouTube and Twitter, we find that both LinkedIn and Twitter are poor fits reporting Nagelkerke $R^{2}$ of $<0.1$ in both cases. However, YouTube with a Nagelkerke $R^{2}$ of 0.112 is predicted by accreditation and interdisciplinary appointments. Specifically, 30.6 percent of those with an interdisciplinary appointment use YouTube, compared to 12.2 percent of those without $(p<0.001)$. In addition, 22.7 percent of faculty in schools at comprehensive universities use YouTube compared to 9.7 percent for research-intensive schools and 7.9 percent for undergraduate schools. Finally, print media with a Nagelkerke $R^{2}$ of 0.028 suggests a poor model fit.

\section{Discussion}

The primary goal of this study was to identify and explore the complex factors that influence management scholars to select different KD outlets. Our results show that the legitimacy of different $\mathrm{KD}$ outlets depends on the audience that the author(s) chose to address. These four main audiences and associated KD outlets include: scholarly KD (e.g. PRJs and ResearchGate), student KD (e.g. textbooks and classrooms), practitioner KD (e.g. collaboration) societal $\mathrm{KD}$ (e.g. social media and print media) are all viewed as legitimate through the eyes of their audiences. As such, greater focus is needed to further understand how individual level factors (Nicolini, 2013) impact the decision to address the issues of these specific audiences.

Our review of relevant literature found limited research attempting to empirically study the structures and processes embedded in the management of universities, business schools 


\section{JIUC 1,2}

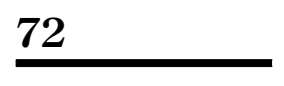

Panel a

Model

Dependent

1
PRJ (FT45)

2

3

variable

PRJ (4+)

PRJ (1-3)

4

5

Independent variables

Strategic

orienta

$2.073^{* * * *}(0.220)$

Accreditation $1.114 * * *(0.271)$

Terminal degree

Practitioner exp.

$114 * * 10.271)$
$0.574 *(0.246)$

$0.574 *(0.246)$
$1.991 * * *(0.359)$

(0.521

$0.446(0.274)$

Interdisciplinary

$\mathrm{PhD}$ rank

Discipline

Gender

Tenured

Constant

Percentage

$0.321(0.260)$

$0.821 *(0.407)$

$-0.280(0.276)$

$0.017(0.030)$

0.259 (0.396)

$0.168(0.308)$

$0.045(0.028)$

$-0.539 *(0.254)$

$-0.604 *(0.244)$

$0.502 *(0.246) \quad 0.983 * * *(0.234)$

$0.502^{*}(0.246)$
$-8.803^{* * *}(0.922)$

$-4.887^{* * * *}(0.645)$

$0.843 * * *(0.166)$

$6.216^{*}(0.255)$

$1.752 * * *(0.356)$

$0.560(0.321)$

$0.233(0.425)$

$0.542(0.389)$

$0.033(0.031)$

$-0.323(0.256)$

$1.261 * * *(0.250)$ correct

$\chi^{2}$

Df
$-2 \log$

likelihood

Cox and Snell $R^{2}$

$\begin{array}{cc}77.8 & 76.3 \\ 225.959^{* * *} & 165.743^{* * *} \\ 8 & 8\end{array}$

488.280

0.351

0.471

519.687
0.272

0.372

Panel b

Model

Dependent

6

variable

In-Class

7

Textbook

publishing

Independent variables

Strategic

orientation

Accreditation

$-0.456^{*}(0.232)$

$0.850 *(0.410)$

Terminal degree

$1.458 * *(0.539)$

Practitioner exp.

$1.189 * *(0.359)$

Interdisciplinary

$0.945 *(0.436)$

$-0.684(0.538)$

$0.027(0.042)$

Discipline

Gender

Tenured

Constant

Percentage

correct

$\chi^{2}$

-2 Log

likelihood

Cox and Snell $R^{2}$

$0.375(0.374)$

$-0.459(0.342)$

$0.624 * *(0.184)$

$0.727 *(0.290)$

$-0.282(0.392)$

$0.467(0.286)$

$0.065(0.402)$

$-0.109(0.297)$

$-0.043(0.031)$

$0.054(0.274)$

$-4.038^{* * *}(0.866)$

$1.305^{* * * *}(0.307)$

Other book
$0.792 *(0.343)$

$-0.376(0.414)$

$1.111(0.807)$

$0.619(0.415)$

$0.875(0.518)$

$0.138(0.437)$

$-0.018(0.050)$

0.335 (0.484)

$0.961 *(0.489)$
$-6.697 * * *(1.288)$

$0.513^{* * * *}(0.144)$

$0.645^{* *}(0.221)$

$1.065^{* *}(0.344)$

$-0.191(0.234)$

$-0.479(0.351)$

$0.324(0.260)$

$-0.039(0.026)$

-0.079 (0.216)

$1.244 * * *(0.213)$

$-2.874 * * *(0.558)$

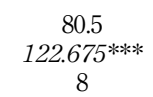

452.553

0.209

0.313

8

publishing

94.1

$24.006^{* *}$

8

$$
\begin{gathered}
0.289 *(0.140) \\
-0.038(0.216) \\
0.335(0.317) \\
0.421(0.233) \\
0.431(0.324) \\
-0.240(0.251) \\
0.004(0.025) \\
-0.386(212)
\end{gathered}
$$

$1.254 * * *(0.225)$
211.306
0.045
0.124

9

Practitioner

engagement

51.4

$114.346^{* * * *}$

8

610.255

0.196

0.262

10

YouTube
Nagelkerke $R^{2}$

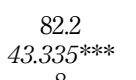

8

455.339
0.080

0.129
$0.156(0.156) \quad-0.189(0.195)$

$0.162(0.239) \quad 0.995 * *(0.350)$

$0.356(0.311) \quad 0.323(0.476)$

$1.262^{* * *}(0.256) \quad-0.020(0.319)$

$0.873 * *(0.326) \quad 1.287 * * *(0.364)$

$-0.552(0.315) \quad 0.610(0.329)$

$0.007(0.028) \quad 0.072 *(0.035)$

$0.039(0.240) \quad-0.483(0.282)$

$-0.109(0.233) \quad 0.296(0.298)$

Table VI.

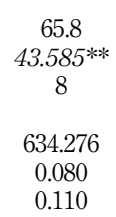

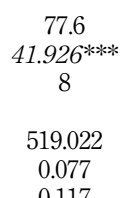

0.117
$0.296(0.298)$
$-3.109 * * *(0.735)$

85.9
33.585

8

389.207

0.062

0.112

Binominal logistic Notes: Panel (a): $n=524$; Panel (b) $n=74$. Models for LinkedIn, Twitter and Print Media all report a Nagelkerke $R^{2}$ of regressions predicting $<0.1$ and are not included in this table. Betas reported. Standard errors (SE) are in parentheses. Significant factors in KD Outcomes

and accreditation agencies. Similar to other disciplines ranging from marketing to human resources, this paper highlights the emerging need to better understand the influence and impact of non-traditional analytics and how they may contribute to more effective evidence-based management. For example, how do we effectively measure the influence of $\mathrm{KD}$ through outlets ranging from social media or our teaching, as citation counts (a uniquely scholar audience measure) do not capture this impact? The effective measurement of these 
outlets is emerging as critical since policymakers are demanding clear assessments of their investment in research including its impact on non-scholarly audiences. The results of this research identify five interrelated themes:

(1) management research serves diverse audiences;

(2) the individual scholar is the key unit of analysis;

(3) the role of peers is essential to career development;

(4) scholar socialization is an antecedent of KD judgments; and

(5) institutional-level pressure is an antecedent of $\mathrm{KD}$ judgments.

These five themes together demonstrate the complex interaction between individual scholar-level factors, including socialization (degree type and practitioner experience) and tenure, and the institutional-level factors, such as strategic orientation and accreditation, and how these influence the focus on audience specific KD outlets. Based on these themes, it is imperative that scholars consider this issue far more holistically and systematically.

First, the finding that institutional factors are a central predictor of scholarly $\mathrm{KD}$ supports the literature that has argued that structural elements, such as tenure and promotion criteria, are influential incentives in directing KD outcomes (Adler and Harzing, 2009; Link et al., 2008).

Second, we identify that individual-level factors including degree, professional experience and career stage play a role in non-scholarly KD. This suggests that as management scholars face increasing pressure to demonstrate impact beyond academia, it may be more difficult than simply adapting the reward system. Specifically, we suggest that administrators and policy makers will have to consider individual factors, including their academic training (including interdisciplinary training), previous practitioner experience and career stage. This supports the contention that previous socialization, both academically and professionally, influences $\mathrm{KD}$ outcomes.

Third, the results highlight a core structural assumption embedded historically in accreditation bodies. Specifically, accreditation bodies assign a minimum standard where a proportion of faculty must require a research-oriented doctorate. Similarly, $\mathrm{PQ}$ faculty must meet standards related to practical engagement. This approach is based on the idea that the aggregation of these faculty offer a bridge between theory and practice, which Hughes et al. (2011) refer to as "either/or." However, our study highlights that management scholars should evaluate the contribution of theory and practice at an individual-scholar level through focused engagement of bridge faculty, as first proposed by Bennis and O'Toole (2005). This finding also supports previous findings that suggest that bridge faculty are both "willing" and "able" to engage practitioner audiences (Hughes et al., 2011, p. 48).

\section{Contributions to theory and practice}

Our findings contribute to theory as our study suggests that the search for legitimacy by management scholars may be more complicated than previously thought. Although management scholars still focus on publications in peer-reviewed journals, our study demonstrates that legitimacy comes from the audience that the research targets. Moreover, our qualitative study suggests that those individuals who occupy significant positions in these schools also recognize the need for management research to address different, if not, multiple audiences. What this seems to suggest is that there are many ways to be a "researcher" and to create impact from within a business school.

Our findings also contribute to practice, as it suggests that business school administrators must continuously reflect on their mission statement and objectives in 
JIUC
1,2

light of the four major audiences identified - scholars, students, practitioners and society. These audiences represent the key communities to management scholars. In particular, with austerity measures being imposed upon publicly funded institutions, resources for research will need to be found from non-traditional sources. This means that audiences from outside the academy will play an even greater role in funding scholarship. To do so, management scholars will have to understand the $\mathrm{KD}$ channels they perceive as legitimate. Finally, our findings provide evidence that $\mathrm{KD}$ diversification is deeply rooted at both the individual and institutional level. As a result, administrators most focus at this issue holistically and deal with the root causes at both the individual and institutional level.

\section{Limitations and future research}

This study is theoretically framed using communication theory and considers the influence of both the individual scholars and institutional level factors on the choice of nine KD outlets. While our models performed well in capturing the factors associated with scholarly and teaching-oriented $\mathrm{KD}$, they did not perform as well for practitioner or societal $\mathrm{KD}$ efforts. This performance may be a result of deriving factors from a qualitative study of senior business school administrators, scholars and community members closely associated with management research. As such it is an indication that certain types of impact are captured, but that this is not the case for all the audiences that engage with the business school. Future studies should seek to understand $\mathrm{KD}$ outreach to other audiences and focus on factors associated with individual outputs and activities, perhaps including membership in professional societies, paid consulting activities, or advisory roles taken with local community organizations.

The findings also lead to a question of the ideal composition of scholars to ensure $\mathrm{KD}$ occurs to a diverse range of business school audiences. As funding agencies continue to demand that scholars effectively disseminate their findings to diverse audiences, the academy needs to explore questions of scholars composition and/or whether institutions with different orientations can (or should be) specialized at the creation and dissemination of new knowledge to a breadth of audiences. In addition, our measures are limited based on the cross-sectional data gathered from publically available sources; future research should consider longitudinal methods that incorporate scholars interviews to provide additional depth and context to both biographical and KD measures. For instance, the measurement of practitioner experience could incorporate AACSB Standard 15 and its 2013 definition of professionally qualifications regarding the length of tenure and level of responsibility as factors contributing to practitioner experience.

Future research should also explore in greater depth the specific forms of $\mathrm{KD}$ and the link between content and outlet. For instance, future research should consider emerging social media tools that allow content analysis and examine how these outlets are used to communicate academic knowledge to non-scholarly audiences. Moreover, research could focus on the characteristics that different institutions attach to their faculty members and how these and other contextual factors help predict the selection of specific KD outlets. Similarly, additional attention could be played to the role of discipline expertise in predicting KD outcomes. This has interesting implications given that tenure and promotion is often at an institutional level. Future research should explore why certain disciplines appear to stimulate (or act as a barrier) to different forms of $\mathrm{KD}$ ranging from peer-reviewed publications to books or active engagement in practice. To conclude, in this study we address recent recommendations (Hughes et al., 2011) to examine individual and institutional level factors that influence KD outcomes by management scholars. Results support that $\mathrm{KD}$ activities are influenced by factors at both the individual and institutional level. 


\section{Notes}

1. Jensen (2010) used the French academic classification of Compte Rendus Annuels des Chercheurs.

2. This study used membership in the Canadian Federation of Business School Deans (CFBSD) to define the population of university-level business programs in Canada. For more information on CFBSD, see www.cfbsd.ca.

3. The U15 is a group of 15 research-intensive universities and represents 80 percent of all competitively funded Canadian university research. For more information refer to www.U15.ca

4. The regional stratification considered four regions: eastern Canada, Quebec, Ontario and western Canada.

\section{References}

AACSB (2013), "Eligibility procedures and accreditation standards for business accreditation", available at: www.aacsb.edu/en/accreditation/standards/2013-business/ (accessed May 21, 2019).

Adler, N.J. and Harzing, A. (2009), "When knowledge wins: transcending the sense and nonsense of academic rankings", Academy of Management Learning \& Education, Vol. 8, pp. 72-95.

Adler, N.J. and Hansen, H. (2012), "Daring to care scholarship that supports the courage of our convictions", Journal of Management Inquiry, Vol. 21, pp. 128-139.

Aguinis, H., Shapiro, D.L., Antonacopoulou, E.P. and Cummings, T.G. (2014), "Scholarly impact: a pluralist conceptualization", Academy of Management Learning \& Education, Vol. 13, pp. 623-639.

Bedeian, A.G., Taylor, S.G. and Miller, A.N. (2010), "Management science on the credibility bubble: cardinal sins and various misdemeanors", Academy of Management Learning \& Education, Vol. 9, pp. 715-725.

Bekkers, R. and Freitas, I.M.B. (2008), "Analysing knowledge transfer channels between universities and industry: to what degree do sectors also matter?", Research Policy, Vol. 37, pp. 1837-1853.

Bennis, W.G. and O’Toole, J. (2005), "How business schools lost their way", Harvard Business Review, Vol. 83, pp. 96-104.

Boyer E.L. (1998), "Reinventing undergraduate education: a blueprint for America's research universities", Boyer Commission on Educating Undergraduates in the Research University, State University of New York at Stony Brook for the Carnegie Foundation for the Advancement of Teaching, Stony Brook, NY.

Brown, R.B. (2005), "Mapping the temporal landscape the case of university business school academics", Management Learning, Vol. 36 No. 4, pp. 451-470.

Burke, L.A. and Rau, B. (2010), "The research-teaching gap in management”, Academy of Management Learning \& Education, Vol. 9, pp. 132-143.

Certo, S.T., Sirmon, D.G. and Brymer, R.A. (2010), "Competition and scholarly productivity in management: investigating changes in scholarship from 1988 to 2008", Academy of Management Learning \& Education, Vol. 9, pp. 591-606.

Chia, R. and Holt, R. (2008), "The nature of knowledge in business schools", Academy of Management Learning \& Education, Vol. 7, pp. 471-486.

Clarke, T., Bajada, C. and Trayler, R. (2013), "Interdisciplinary business education: curriculum through collaboration", Education + Training.

Connelly, C.E. and Gallagher, D.G. (2010), "Making 'the list': the business school rankings and the commodification of business research", Journal of Curriculum Theorizing, Vol. 26 No. 3.

Creswell, J.W. (1998), Qualitative Inquiry and Research Design: Choosing Among Five Designs, Sage, Thousand Oaks, CA.
Impact of management research 
JIUC
1,2

Davies, H., Nutley, S. and Walter, I. (2005), "Assessing the impact of social science research: conceptual, methodological and practical issues", Research Unit for Research Utilisation, University of St Andrews, St. Andrews, available at: www.st-andrews.ac.uk/ ruru

Deephouse, D.L. (1996), "Does isomorphism legitimate?", Academy of Management Journal, Vol. 39, pp. 1024-1039.

Deephouse, D.L. and Suchman, M. (2008), "Legitimacy in organizational institutionalism", in Greenwood, R., Oliver, C., Sahlin, K. and Suddaby, R. (Eds), The Sage Handbook of Organizational Institutionalism, Sage, Thousand Oaks, CA, pp. 49-77.

Dietz, J.S. and Bozeman, B. (2005), "Academic careers, patents, and productivity: industry experience as scientific and technical human capital”, Research Policy, Vol. 34, pp. 349-367.

Durand, R. and McGuire, J. (2005), "Legitimating agencies in the face of selection: the case of AACSB", Organization Studies, Vol. 26, pp. 165-196.

Engwall, L. and Kipping, M. (2004), "The dissemination of management knowledge”, Management Learning, Vol. 35 No. 3, pp. 243-253.

Erkut, E. (2002), "Measuring Canadian business school research output and impact", Canadian Journal of Administrative Sciences, Vol. 19 No. 2, pp. 97-123.

Everard, A., Edmonds, J. and St Pierre, K. (2013), "The longitudinal effects of the mission-driven focus on the credibility of the AACSB", Journal of Management Development, Vol. 32, pp. 995-1003.

Fairweather, J.S. (2002), "The mythologies of faculty productivity: implications for institutional policy and decision making", The Journal of Higher Education, Vol. 73 No. 1, pp. 26-48.

Finch, D.J., Varella, P., Foster, W., Sundararajan, B., Bates, K., Nadeau, J., O’Reilly, N. and Deephouse, D.L. (2016), "The business school scorecard: examining the systematic sources of business school value", Canadian Journal of Administrative Sciences/Revue Canadienne des Sciences de l'Administration, Vol. 33 No. 4, pp. 277-289.

Gibbons, M., Limoges, C., Nowotny, H., Schwartzman, S., Scott, P. and Trow, M. (1994), The New Production of Knowledge: The Dynamics of Science And Research in Contemporary Societies, Sage, Thousand Oaks, CA.

Gomez-Mejia, L.R. and Balkin, D.B. (1992), "Determinants of faculty pay: an agency theory perspective", Academy of Management Journal, Vol. 35, pp. 921-955.

Hommel, U. and Thomas, H. (2014), "Research on business schools", in Pettigrew, A.M., Hommel, U. and Comuel, E. (Eds), The Institutional Development of Business Schools, Oxford University Press, Oxford, pp. 6-37.

Hughes, T., Bence, D., Grisoni, L., Oregan, N. and Wornham, D. (2011), "Scholarship that matters: academic-practitioner engagement in business and management", Academy of Management Learning \& Education, Vol. 10, pp. 40-57.

Jensen, P. (2010), "A statistical picture of popularization activities and their evolutions in France", Public Understanding of Science.

Kantola, A. and Seeck, H. (2011), "Dissemination of management into politics: Michael Porter and the political uses of management consulting”, Management Learning, Vol. 42 No. 1, pp. 25-47.

Kieser, A. and Leiner, L. (2011), "On the social construction of relevance: a rejoinder", Journal of Management Studies, Vol. 48, pp. 891-898.

Landry, R., Amara, N. and Ouimet, M. (2007), "Determinants of knowledge transfer: evidence from Canadian university researchers in natural sciences and engineering", The Journal of Technology Transfer, Vol. 32, pp. 561-592.

Lim, A., Qing, D.C.J. and Eyring, A.R. (2014), "Netting the evidence: a review of on-line evidence-based management resources", Academy of Management Learning \& Education, Vol. 13, pp. 495-503.

Linehan, M. and Walsh, J.S. (2001), "Key issues in the senior female international career move: a qualitative study in a European context", British Journal of Management, Vol. 12, pp. 85-95.

Link, A.N., Swann, C.A. and Bozeman, B. (2008), "A time allocation study of university faculty", Economics of Education Review, Vol. 27, pp. 363-374. 
Lounsbury, M. and Crumley, E.T. (2007), "New practice creation: an institutional perspective on innovation”, Organization Studies, Vol. 28, pp. 993-1012.

Marcos, J. and Denyer, D. (2012), "Crossing the sea from they to we? The unfolding of knowing and practising in collaborative research", Management Learning, Vol. 43 No. 4, pp. 443-459.

Mohrman, S.A., Gibson, C.B. and Mohrman, A.M. (2001), "Doing research that is useful to practice a model and empirical exploration", Academy of Management Journal, Vol. 44, pp. 357-375.

Nicolini, D. (2013), Practice Theory, Work, and Organization: An Introduction, Oxford University Press, Oxford.

Palmer, T.B. and Short, J.C. (2008), "Mission statements in US colleges of business: an empirical examination of their content with linkages to configurations and performance", Academy of Management Learning \& Education, Vol. 7, pp. 454-470.

Pangarkar, N. (2007), "Survival during a crisis: alliances by Singapore firms", British Journal of Management, Vol. 18, pp. 209-223.

Paton, S., Chia, R. and Burt, G. (2014), "Relevance or relevate? How university business schools can add value through reflexively learning from strategic partnerships with business", Management Learning, Vol. 45 No. 3, pp. 267-288.

Perriton, L. and Hodgson, V. (2013), "Positioning theory and practice question (s) within the field of management learning”, Management Learning, Vol. 44 No. 2, pp. 144-160.

Pettigrew, A.M., Cornuel, E. and Hommel, U. (2014), "Introduction", in Pettigrew, A.M., Hommel, U. and Comuel, E. (Eds), The Institutional Development of Business Schools, Oxford University Press, Oxford, pp. 1-5.

Pfeffer, J.S. and Salancik, G. (1978), The External Control of Organizations: A Resource Dependence Perspective, Harper \& Row, New York, NY.

Romme, G. (2017), "Management as a science-based profession: a grand societal challenge", Management Research Review, Vol. 40 No. 1, pp. 5-9.

Rynes, S.L. and Brown, K.G. (2011), “Where are we in the 'long march to legitimacy?' Assessing scholarship in management learning and education", Academy of Management Learning \& Education, Vol. 10, pp. 561-582.

Scott, W.R. (2008), Institutions and Organizations: Ideas And Interests, Sage Publications, Los Angeles, CA.

Soule, D.L. and Edmondson, A.C. (2001), "Situated knowledge and learning in dispersed teams", British Journal of Management, Vol. 13, pp. S17-S34.

Statistics Canada (2009), "Postsecondary enrolment and graduation", Statistics Canada, Ottawa, October, available at: www.statcan.gc.ca/pub/81-599-x/81-599-x2009003-eng.htm (accessed April 29, 2015).

Suchman, M.C. (1995), "Managing legitimacy: strategic and institutional approaches", Academy of Management Review, Vol. 20, pp. 571-610.

Suddaby, R. and Greenwood, R. (2005), "Rhetorical strategies of legitimacy", Administrative Science Quarterly, Vol. 50, pp. 35-67.

Tabachnick, B.G. and Fidell, L.S. (1996), Using Multiple Statistics, Harper \& Row, New York, NY.

Thelwall, M. and Kousha, K. (2014), “Academia. edu: social network or academic network?”, Journal of the Association for Information Science and Technology, Vol. 65, pp. 721-731.

Thorpe, R., Eden, C., Bessant, J. and Ellwood, P. (2011), "Rigour, relevance and reward: introducing the knowledge translation value-chain”, British Journal of Management, Vol. 22, pp. 420-431.

Tost, L.P. (2011), "An integrative model of legitimacy judgments", Academy of Management Review, Vol. 36, pp. 686-710.

Van de Ven, A.H. and Johnson, P.E. (2006), "Knowledge for theory and practice", Academy of Management Review, Vol. 31, pp. 802-821. 
Wong, F.K., Kember, D., Chung, L.Y. and CertEd, L.Y. (1995), "Assessing the level of student reflection from reflective journals", Journal of Advanced Nursing, Vol. 22, pp. 48-57.

Wu, Y.J., Huang, S., Kuo, L. and Wu, W. (2010), "Management education for sustainability: a web-based content analysis", Academy of Management Learning \& Education, Vol. 9, pp. 520-531.

\section{Further reading}

Filatotchev, I. and Bishop, K. (2002), "Board composition, share ownership, and underpricing of UK IPO firms", Strategic Management Journal, Vol. 23, pp. 941-955.

Goranova, M., Alessandri, T.M., Brandes, P. and Dharwadkar, R. (2007), "Managerial ownership and corporate diversification: a longitudinal view”, Strategic Management Journal, Vol. 28, pp. 211-225.

Gordon, R.A. and Howell, J.E. (1959), Higher Education for Business, Columbia University Press, New York, NY.

Gulati, R. and Higgins, M.C. (2003), "Which ties matter when? The contingent effects of interorganizational partnerships on IPO success", Strategic Management Journal, Vol. 24, pp. 127-144.

Miller, T. and del Carmen Triana, M. (2009), "Demographic diversity in the boardroom: mediators of the board diversity-firm performance relationship", Journal of Management Studies, Vol. 46, pp. 755-786.

Musteen, M., Datta, D.K. and Kemmerer, B. (2010), "Corporate reputation: do board characteristics matter?”, British Journal of Management, Vol. 21, pp. 498-510.

Pearce, J.L. and Huang, L. (2012), "The decreasing value of our research to management education", Academy of Management Learning \& Education, Vol. 11, pp. 247-262.

Pierson, F.C. (1959), The Education of American Businessmen: A Study of University-College Programs in Business Administration, McGraw-Hill, New York, NY.

Rynes, S.L., Bartunek, J.M. and Daft, R.L. (2001), "Across the great divide: knowledge creation and transfer between practitioners and academics", Academy of Management Journal, Vol. 44, pp. 340-355.

Starkey, K. and Madan, P. (2001), "Bridging the relevance gap: Aligning stakeholders in the future of management research", British Journal of Management, Vol. 12, pp. S3-S26.

Starkey, K., Hatchuel, A. and Tempest, S. (2009), "Management research and the new logics of discovery and engagement", Journal of Management Studies, Vol. 46, pp. 547-558.

\section{Corresponding author}

David J. Finch can be contacted at: dfinch@mtroyal.ca

For instructions on how to order reprints of this article, please visit our website: 